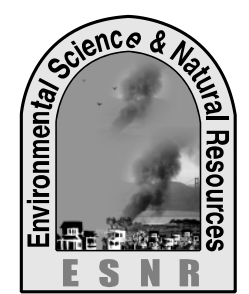

\title{
Textural Influence on Surface and Subsurface Soil Temperatures under Various Conditions
}

\author{
M. Akter, M. A. Miah, M. M. Hassan, M. N. Mobin and M. A. Baten* \\ Department of Environmental Science \\ Bangladesh Agricultural University, Mymensingh \\ *Corresponding author: baten_envsc@yahoo.com
}

\begin{abstract}
An experiment was conducted at the field laboratory of Department of Environmental Science, Bangladesh Agricultural University, Mymensingh to study the textural influence on surface and subsurface soil temperatures under various conditions. The experiment consisted of four types of soil (red, sandy, clay and peat). Observations were made at three conditions viz. bare, moist and vegetation cover. Sandy soil at bare condition showed the highest surface temperature followed by peat, red and clay soils. Sand surface produced nearly $10^{\circ} \mathrm{C}$ higher values than from clay soil at around midday hours. In four types of soils, the amplitude of the daily surface temperature wave decreased in the order sand > peat > red > clay at bare dry condition. In case of subsurface temperature observed at $10 \mathrm{~cm}$ depth, red, clay and peat soils showed insignificant differences. Soil surface temperatures of 4 types soils under moisture condition at around mid days showed similar pattern as in dry condition i.e. sand > peat $>$ red $>$ clay. Soil subsurface temperatures of 4 types soils under moisture condition at around mid days showed similar pattern as in surface temperature. Among three conditions, sandy soil emitted highest long wave radiation $\left(-649.88 \mathrm{Wm}^{-2}\right)$ at bare condition. The long wave radiation emitted by the surface was lower when the soil was wet and has vegetation cover. Air temperature positively correlated with soil temperature.
\end{abstract}

Key words: Soil temperature, Soil texture, Surface temperature, Sub-surface temperature

\section{Introduction}

Soil temperature is one of the important factors that control the microbiological activity and all the processes involved in the growth of plants. The temperature of the soil is an important but often overlooked variable, affecting root growth, water and nutrient uptake, root metabolism, microbial activity, decomposition of organic matter, soil chemistry, and soil moisture levels (Gliessman, 1998). The rate of physical, chemical, and biological processes is directly related to the changes in the soil temperature. Soil temperature influences water and nutrient uptake, metabolic processes root and shoot growth (Hogue and Neilsen, 1986). Natural fluctuations in the soil temperature occur daily and annually as a result of seasonal and diurnal changes in the amount of incident solar radiation or sunlight (Hillel, 1982). Temperature change is also caused by variation in air temperature, moisture content, soil color, slope of land, and vegetation cover. Vegetation also controls the amount of sunlight that can reach the ground surface. Bare soil cools and warms faster than vegetated soil that is insulated by vegetation (Brady et. al., 1999). Variations in soil temperature and moisture alter the partitioning of sensible and latent heat from the surface and affect atmospheric boundary layer processes and regional circulation (Pan and Mahrt, 1987). The amount of received radiation affects soil temperature and varies depending on the aspect, slope, and percent canopy cover (Russell, 1973). Soil temperature affects the surface heat flux at various timescales. Because heat conduction in soils is a very slow process, soil heat anomalies of daily or weekly timescales in shallow layers near the surface are released to the atmosphere before being distributed to the deeper layers (Cyril and Ogagarue, 2012). Soil texture has important role in temperature variation because each type of soil made of unique textural characteristics. Sandy soils warm up more rapidly in the spring than do clay soils. It is due to lower heat capacity, lower thermal conductivity, and less evaporative chilling. Yakuwa, 1946 and Chang,
1968 conducted an experiment on soil temperature in different soil types of Hokkaido, Japan (43.06 N Latitude and 141.34 E Longitude) and found that soil texture had distinct influence on soil temperature and soil surface temperature. The amplitude of the daily temperature wave decreases in the order in the order sand $>$ loam $>$ peat $>$ clay. The presence of moisture at the surface and in the subsurface soil greatly moderates the diurnal range of surface temperatures. Soil temperatures depend on a number of factors, which also determine the surface temperature. Keeping all these views in mind the research was under taken with the specific objectives to measure surface and subsurface soil temperatures under bare, moisture, vegetation cover condition and to evaluate the textural influence on the emission of long wave radiation.

\section{Materials and Methods}

The experiment was conducted at the field laboratory of the Department of Environmental Science, Bangladesh Agricultural University (BAU), Mymensingh during the period from August to November 2013. The soil of the experimental site was non-calcareous dark gray floodplain.

\section{Measurement of surface temperature}

Soil surface temperature was measured through Infrared Thermometer (CEM DT-8818H, China) on clear sunny day. Soil subsurface temperature at $10 \mathrm{~cm}$ depth was measured through a POGO Portable Soil sensorOriginal (POGO with PDA and Hydramon Software, China) on clear sunny day. Textural classes were determined by hydrometer method as outlined by Bouyoucos (1927). The textural classes were then determined by plotting the result on Marshall's triangular coordinate designed by Marshall (1988). Twenty four hours data starting from 6.00 AM were collected. 


\section{Measurement of long wave radiation of soil}

The upward long wave radiation was calculated from the surface temperature and emissivity using the StefanBoltzmann law (Ellingson, 1995). Soil temperature (Ts) was measured using the modified Stefan-Boltzmann equation: $\mathbf{R} \boldsymbol{\uparrow} \uparrow=-\in \sigma \boldsymbol{T}^{4}$

where, the negative sign is introduced in accordance with our sign convention for radiative fluxes i.e. flux towards space/away from the surface.

\section{Measurement of micrometeorological parameters}

The secondary data of micrometeorological parameters were collected from a tower of the Micrometeorology Laboratory, Department of Environmental Science, Bangladesh Agricultural University (BAU). Solar radiation was measured using pyranometer (Four Component Radiometer MR-40, Eko). To measure airtemperature and relative-humidity at different levels Platinum resistance thermometer and at different levels Humicap (HMP45A, Vaisala, Finland) was used. The Vaisala sensors were placed at two different heights $(1.65,2.95 \mathrm{~m})$ from the soil surface. The first sensor was set on a tower at canopy level $1.65 \mathrm{~m}$ and second was placed at $2.95 \mathrm{~m}$ from the soil surface. For measuring wind direction or wind speed three cup anemometer 03101 (Young, USA) at different height $1.40 \mathrm{~m}, 2.10 \mathrm{~m}$, and $3.10 \mathrm{~m}$ were used. The experiment was based on temperature measurement in different types of soils. Four types of soils were selected namely red soil, sandy soil, clay soil and peat soil. Each types of soil had unique structure and texture. The experimental land was divided into four unit plots with $50 \mathrm{~cm}$ depth, wide and length.

\section{Results and Discussion}

\section{Measurement of surface temperature under bare soil condition}

In bare soil condition, average highest temperature was observed $54.2^{\circ} \mathrm{C}$ at noon (1300 hours) and average lowest temperature observed $23.15^{\circ} \mathrm{C}$ at 2300 hours. Soil surface temperature at noon was high and decreased with time (Fig. 1).

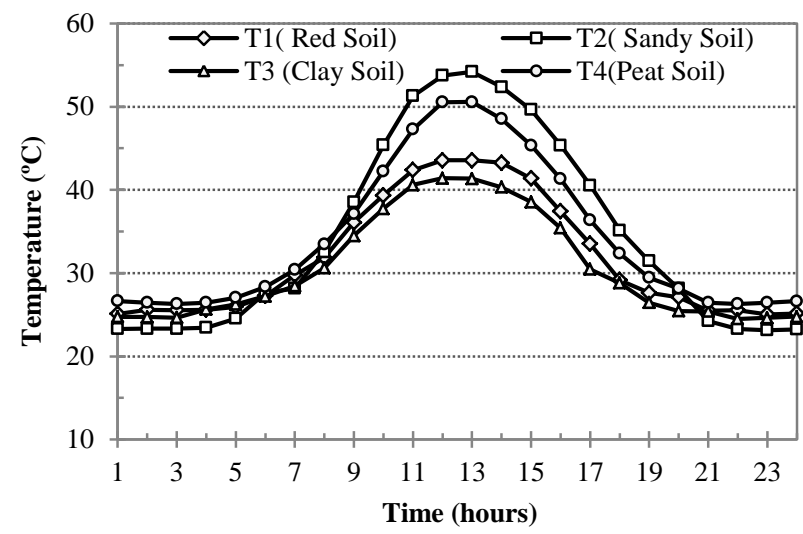

Fig. 1. Soil surface temperature under bare soil condition

In $\mathrm{T} 1$ (red soil), average highest temperature was observed $43.56^{\circ} \mathrm{C}$ and average lowest temperature was $25.05^{\circ} \mathrm{C}$. In $\mathrm{T} 2$ (sandy soil), temperature range was $23.15^{\circ} \mathrm{C}$ to $54.2^{\circ} \mathrm{C}$. In T3 (clay soil), temperature range was $24.49^{\circ} \mathrm{C}$ to $41.4^{\circ} \mathrm{C}$. In $\mathrm{T} 4$ (peat soil), temperature range was 26.3 to $50.55^{\circ} \mathrm{C}$. In four types of soil the amplitude of the daily temperature wave decreased in the order like sand $>$ peat $>$ red $>$ clay. In the Fig. 1 . clearly showed that the diurnal changes in soil temperature gradually increased soon after sun rise, reached a peak at about 1200 to 1400 hours and then decreased smoothly until the next sunrise.

\section{Measurement of subsurface temperature under bare} soil condition

A depth of $10 \mathrm{~cm}$ was selected for measuring subsurface soil temperatures. In bare soil condition, average maximum temperature was observed $42.33^{\circ} \mathrm{C}$ at 1400 hours and average minimum temperature was observed $23.29^{\circ} \mathrm{C}$ at 2100 hours.

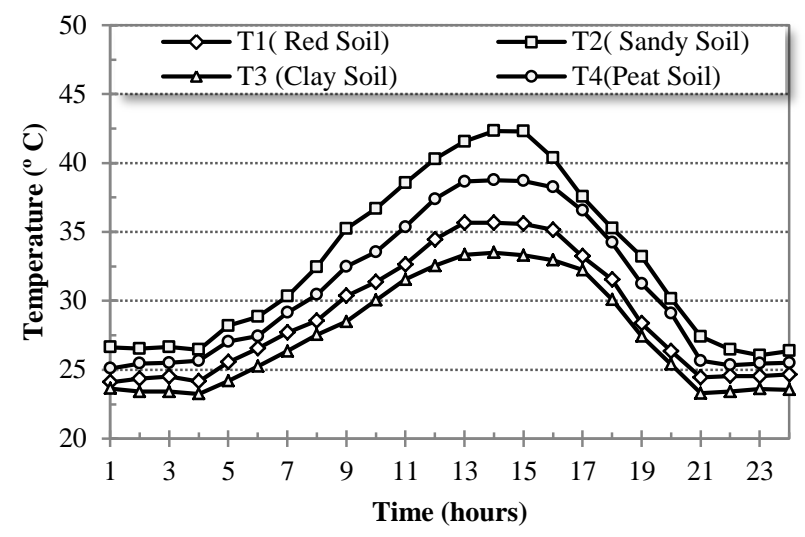

Fig. 2. Soil subsurface temperature at $10 \mathrm{~cm}$ depth under bare soil condition

In T1 (red soil), average maximum temperature was observed $35.66^{\circ} \mathrm{C}$ and average minimum temperature was $24.1^{\circ} \mathrm{C}$. In T2 (sandy soil), temperature range was $26.05^{\circ} \mathrm{C}$ to $42.33^{\circ} \mathrm{C}$. In $\mathrm{T} 3$ (clay soil), temperature range was $23.29^{\circ} \mathrm{C}$ to $32.95^{\circ} \mathrm{C}$. In $\mathrm{T} 4$ (peat soil), temperature range was $25.1^{\circ} \mathrm{C}$ to $38.75^{\circ} \mathrm{C}$. Fig. 2 shows the diurnal changes in subsurface temperature gradually increased at noon, reached a peak at about 1300 to 1600 hours and decreased with time. Subsurface temperature was comparatively lower than surface temperature. Variations in subsurface temperatures among the treatments was due to heat capacity and thermal conductivity.

\section{Measurement of surface temperature under moist soil condition}

In moist soil condition, average highest temperature was $39.75^{\circ} \mathrm{C}$ at noon (1200 hours) and average lowest temperature was $21.51^{\circ} \mathrm{C}$ at 400 hours. From the Fig. 3 in $\mathrm{T} 1$ (red soil), average highest temperature was $37.59^{\circ} \mathrm{C}$ and average lowest temperature was $22.33^{\circ} \mathrm{C}$. In T2 (sandy soil), temperature range was $24.42{ }^{\circ} \mathrm{C}$ to $39.75^{\circ} \mathrm{C}$. In $\mathrm{T} 3$ (clay soil), temperature range was 21.51 ${ }^{\circ} \mathrm{C}$ to $36.07^{\circ} \mathrm{C}$. In $\mathrm{T} 4$ (peat soil), temperature range was $23.25{ }^{\circ} \mathrm{C}$ to $38.65{ }^{\circ} \mathrm{C}$. In moist condition surface temperature did not exceed $40{ }^{\circ} \mathrm{C}$ whereas under bare condition highest temperature was $54.2{ }^{\circ} \mathrm{C}$. The presence of moisture at the surface greatly moderated the diurnal range of surface temperatures. This is due to increased evaporation from the surface, and also due to increased heat capacity and thermal conductivity of the 
soil (Ayra, 2001). Surface temperatures during the day were uniformly lower under moisture condition than over a bare soil surface.

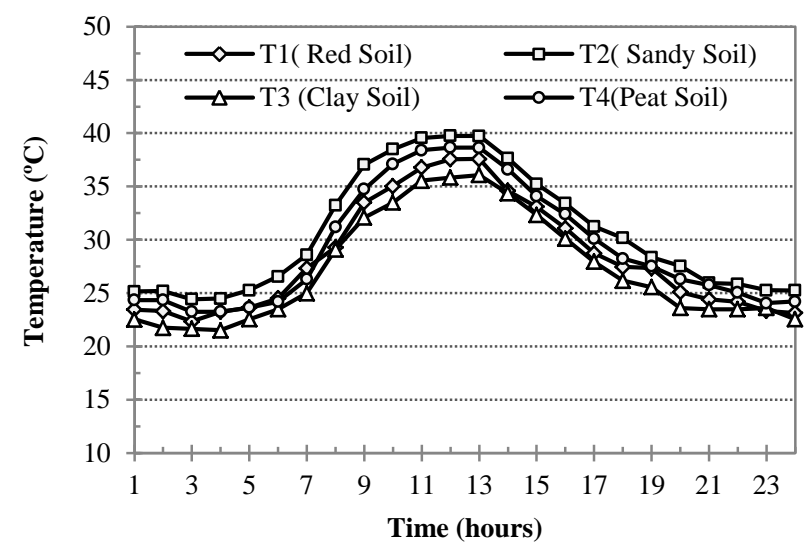

Fig. 3. Soil surface temperature under moist soil moisture condition

\section{Measurement of subsurface temperature under moist soil condition}

In moist soil condition, average maximum temperature was $33.65{ }^{\circ} \mathrm{C}$ at noon (1500 hours) and average minimum temperature was $25.12^{\circ} \mathrm{C}$ at 700 hours.

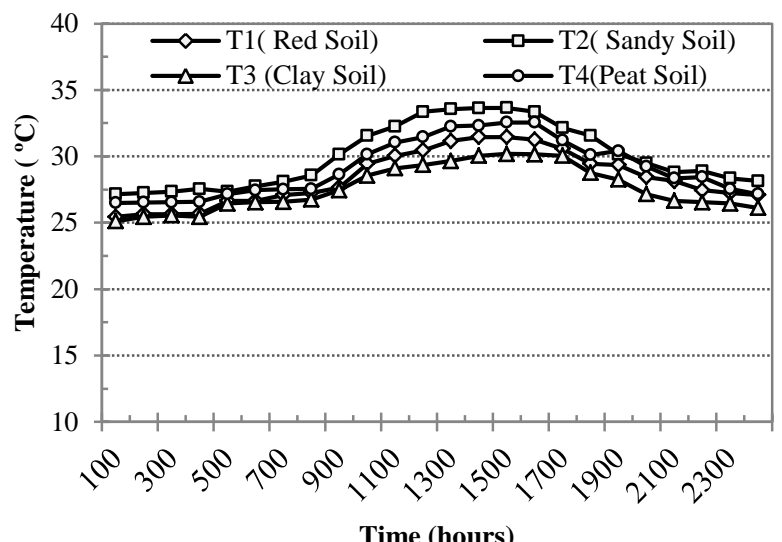

Fig. 4. Soil subsurface temperature at $10 \mathrm{~cm}$ depth under moist soil condition

From the Fig. 4, in $\mathrm{T} 1$ (red soil), maximum average temperature was observed $31.45{ }^{\circ} \mathrm{C}$ and minimum average temperature was $25.45^{\circ} \mathrm{C}$. In T2 (sandy soil), temperature range was $26.15^{\circ} \mathrm{C}$ to $33.65^{\circ} \mathrm{C}$. In T3 (clay soil), temperature range was $25.12^{\circ} \mathrm{C}$ to $30.18^{\circ} \mathrm{C}$. In $\mathrm{T} 4$ (peat soil), temperature range was $26.5{ }^{\circ} \mathrm{C}$ to $32.55^{\circ} \mathrm{C}$. The presence of moisture at the surface and in the subsurface soil greatly moderates the diurnal range of surface. This is due to increased evaporation from the surface, and also due to increased heat capacity and thermal conductivity of the soil (Ayra, 2001).

\section{Measurement of surface temperature under soil vegetation condition}

In soil vegetation cover condition, average highest temperature was $40.4{ }^{\circ} \mathrm{C}$ at noon (1400 hours) and average lowest temperature observed $21.25^{\circ} \mathrm{C}$ at 2400 hours. From the Figure 5 in $\mathrm{T} 1$ (red soil), average highest temperature observed $35.53{ }^{\circ} \mathrm{C}$ and average lowest temperature was $22.28{ }^{\circ} \mathrm{C}$. In $\mathrm{T} 2$ (sandy soil), temperature range was $24.35^{\circ} \mathrm{C}$ to $40.4{ }^{\circ} \mathrm{C}$. In $\mathrm{T} 3$ (clay soil), temperature range was $21.25^{\circ} \mathrm{C}$ to $34.26^{\circ} \mathrm{C}$. In $\mathrm{T} 4$ (peat soil), temperature range was $23.05^{\circ} \mathrm{C}$ to $37.05^{\circ} \mathrm{C}$. The presence of vegetation on the surface reduces the diurnal range of surface temperatures. Part of the incoming solar radiation is intercepted by plant surfaces, reducing amount reaching the surface (Ayra, 2001).

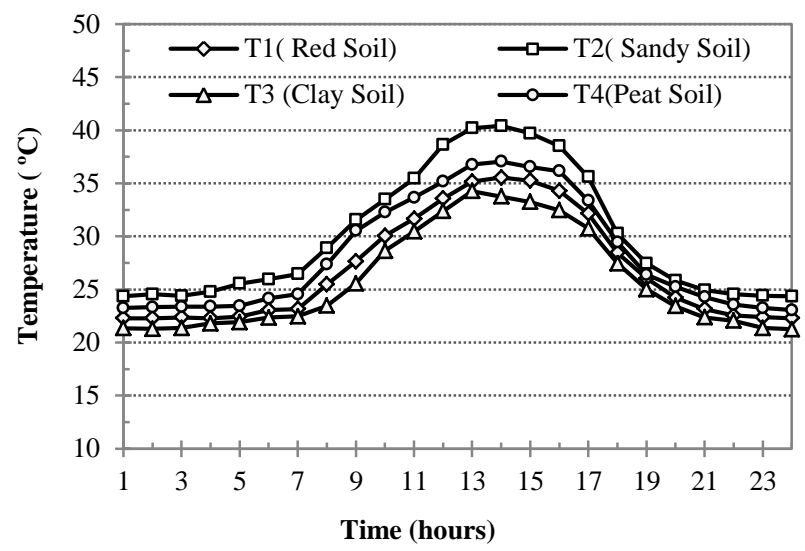

Fig. 5. Soil surface temperatures under soil vegetation cover condition

\section{Measurement of subsurface temperature under soil vegetation condition}

A depth of $10 \mathrm{~cm}$ was selected for measuring subsurface soil temperatures. In soil vegetation cover condition, average maximum temperature of subsurface was observed $31.53{ }^{\circ} \mathrm{C}$ at noon (1400 hours) and average minimum temperature was observed $22.23^{\circ} \mathrm{C}$ at 100 hours. From the Fig. 6, in T1 (red soil), average highest temperature was $28.56{ }^{\circ} \mathrm{C}$ and average lowest temperature was $22.36{ }^{\circ} \mathrm{C}$. In $\mathrm{T} 2$ (sandy soil), temperature range was $24.34^{\circ} \mathrm{C}$ to $31.53^{\circ} \mathrm{C}$. In T3 (clay soil), temperature range was $22.23^{\circ} \mathrm{C}$ to $27.45^{\circ} \mathrm{C}$. In T4 (peat soil), temperature range was $23.26{ }^{\circ} \mathrm{C}$ to $30.12^{\circ} \mathrm{C}$. Temperature gradually increased soon after sun rise, reached a peak at about 1400 to 1600 hours and then decreased smoothly until the next sunrise. The presence of vegetation on the surface also reduces the diurnal range of surface temperatures, as the temperature of surface is decreased than subsurface temperature will reduce automatically (Ayra, 2001).

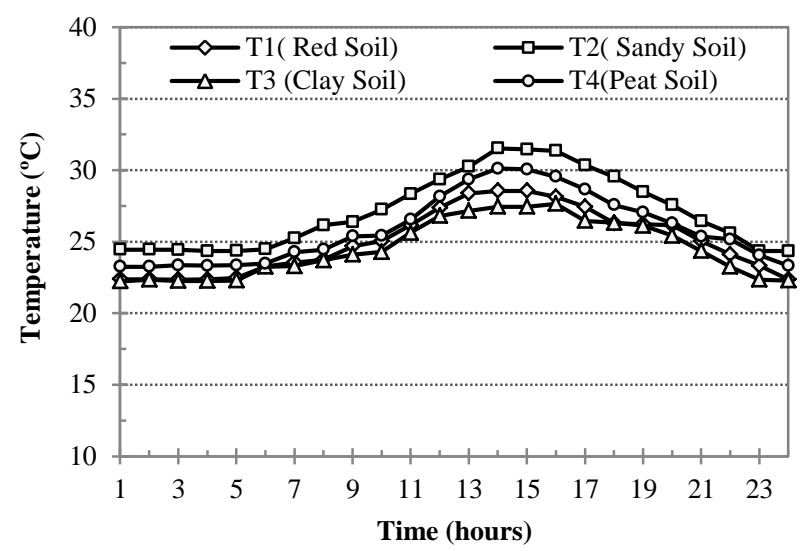

Fig. 6. Soil subsurface temperature at $10 \mathrm{~cm}$ depth under soil vegetation condition 


\section{Measurement of soil texture}

Soil texture has a distinct influence on soil heat flux and, hence, on soil temperature. The finer textured materials have greater heat capacity and greater thermal conductivity. It is instructive to speculate on the pattern of warming in a sandy (coarse textured) and a silt loam (fine textured) in spring. At the end of winter both soils would be saturated. Their thermal conductivity may be about equal at saturation. Texture of four types of soil was measured to identify the influence of temperature variations in different soil. The textural class of a soil

Table 1. Textural classification of soil was determined by the percentage of sand, silt, and clay. Table 1, show textural classification of soil used to conduct the study.A fine-textured soil tends to absorb much water and become plastic and sticky when wet, and tight compact and cohesive when dry. Water move through clays more slowly but because they have a lot of small pores, they tend to retain more water. This is why clay soil exhibits lowest temperature than other three types of soil and the amplitude of the daily temperature wave decreases in the order like sand > peat $>$ red $>$ clay.

\begin{tabular}{|l|c|c|c|l|}
\hline \multicolumn{1}{|c|}{ Soil name } & Sand \% & Silt \% & Clay \% & \multicolumn{1}{c|}{ Textural class } \\
\hline T1 (red soil) & 13.22 & 79.48 & 7.48 & Silt loam (fine textured) \\
\hline T2 (sandy) & 96.56 & 1 & 2.44 & Sand (coarse textured) \\
\hline T3 (clay) & 11.12 & 76 & 12.88 & Silt loam (fine textured) \\
\hline T4 (peat) & 53.12 & 28 & 18.88 & Silt loam (fine textured) \\
\hline
\end{tabular}

\section{Textural influence on the emission of long wave radiation}

\section{Bare condition}

In bare soil condition, at night time emission of long wave radiation is low while the long wave radiation is increasing by the advancement of the day time.

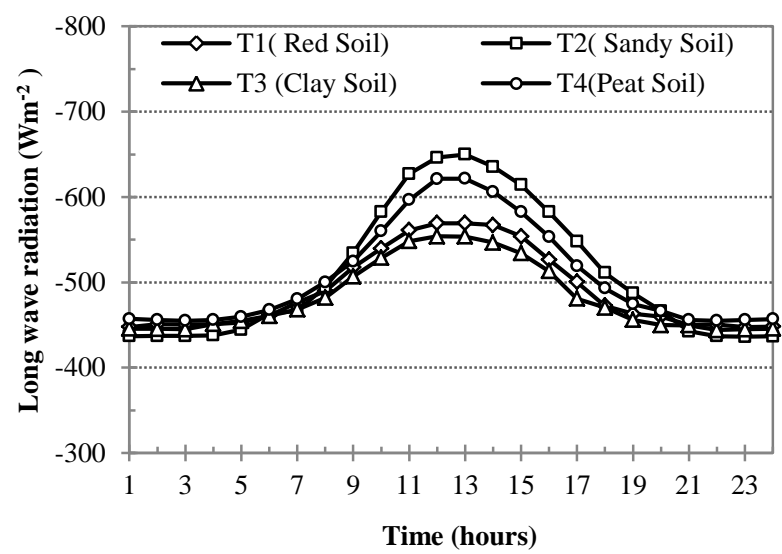

Fig. 7. Emission of long wave radiation from different soil under bare condition

Sandy soil emitted highest long wave radiation (-649.88 $\mathrm{Wm}^{-2}$ ) during the period of $1300 \mathrm{~h}$ and lowest value was $\left(-436.14 \mathrm{Wm}^{-2}\right)$ at $2300 \mathrm{~h}$. Peat soil emitted highest long wave radiation $\left(-621.44 \mathrm{Wm}^{-2}\right)$ at $1300 \mathrm{~h}$ and lowest $(-$ $454.99 \mathrm{Wm}^{-2}$ ). The maximum long wave radiation ($554.00 \mathrm{Wm}^{-2}$ ) was emitted from clay soil at the time $1300 \mathrm{~h}$ and minimum long wave radiation $\left(-444.09 \mathrm{Wm}^{-}\right.$ ${ }^{2}$ ) at 300 hours. At the same time maximum emission from read soil was $-569.38 \mathrm{Wm}^{-2}$ and minimum long wave radiation $\left(-457.43 \mathrm{Wm}^{-2}\right)$ at $100 \mathrm{~h} \mathrm{(Fig.} \mathrm{7).} \mathrm{The}$ amplitude of the daily long wave radiation was in the order of sand $>$ peat $>$ red $>$ clay.

\section{Moisture condition}

In soil moisture condition, sandy soil emitted highest long wave radiation $\left(-542.46 \mathrm{Wm}^{-2}\right)$ during the period of $1200 \mathrm{~h}$ and lowest $\left(-448.04 \mathrm{Wm}^{-2}\right)$ at the time period of $100 \mathrm{~h}$, at the same time maximum $\left(-534.87 \mathrm{Wm}^{-2}\right)$ emission of peat soil at $1200 \mathrm{~h}$. The maximum and minimum value of long wave radiation that emitted from red soil was $-527.43 \mathrm{Wm}^{-2}$ and $-432.69 \mathrm{Wm}^{-2}$ at the time of $1200 \mathrm{~h}$ and $2400 \mathrm{~h}$. The maximum and minimum value of long wave radiation that emitted from clay soil was $-515.90 \mathrm{Wm}^{-2}$ and $-432.67 \mathrm{Wm}^{-2}$ at the time of $1300 \mathrm{~h}$ and $400 \mathrm{~h}$ (Fig. 8).

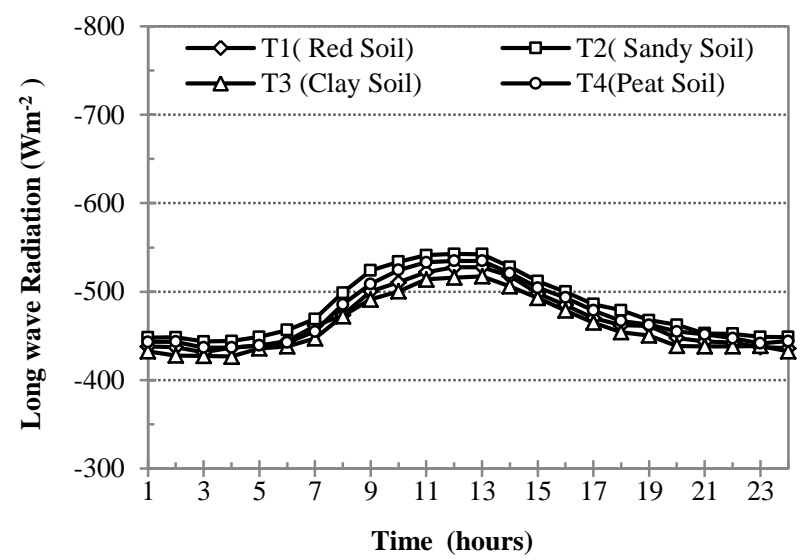

Fig. 8. Emission of long wave radiation from different soil under moisture condition

In moisture condition, the value of long wave radiation was comparatively low than bare condition due to soil saturated with water. The soil surface emitted lowest long wave radiation in the early morning and in the early afternoon. The emissivity of long wave radiation of four soils was more or less nearly. The amplitude of the daily long wave radiation might be shown in the order sand $>$ peat $>$ red $>$ clay.

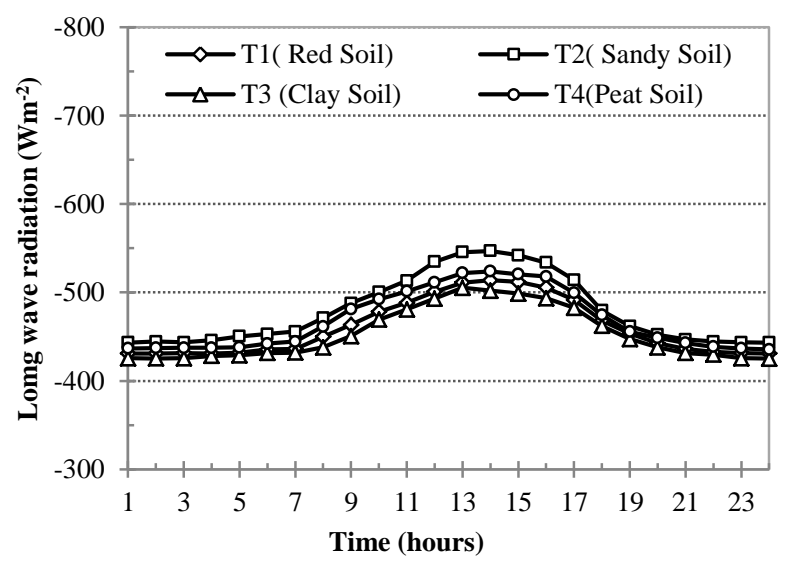

Fig. 9. Emission of long wave radiation from different soil under vegetative condition

Vegetation condition 
In soil vegetation condition, sandy soil emitted highest long wave radiation $\left(-546.98 \mathrm{Wm}^{-2}\right)$ during the period of 1400 hours and lowest long wave radiation was ($443.25 \mathrm{Wm}^{-2}$ ) at the time of $2400 \mathrm{~h}$. The maximum value was recorded from the red, clay, peat soil were $513.77 \mathrm{Wm}^{-2},-505.36 \mathrm{Wm}^{-2}$ and $-523.97 \mathrm{Wm}^{-2}$ respectively and the minimum value were $(-431.09$ $\mathrm{Wm}^{-2},-425.05 \mathrm{Wm}^{-2}$ and $-435.55 \mathrm{Wm}^{-2}$ respectively (Fig. 9). In this condition, value of long wave radiation is comparatively low than bare condition due to soil having vegetation cover. The soil surface emits lowest long wave radiation in the early morning and in the early afternoon.

\section{Conclusions}

In bare soil condition, average highest temperature was $54.2{ }^{\circ} \mathrm{C}$ at noon 1300 hours and average lowest temperature was $23.15^{\circ} \mathrm{C}$ at 2200 hours. The presence of moisture at the surface greatly moderates the diurnal range of surface temperatures. In soil moisture condition, average maximum temperature was $39.75^{\circ} \mathrm{C}$ at noon 1200 hours and average minimum temperature was $21.51{ }^{\circ} \mathrm{C}$ at 400 hours. In soil vegetation cover condition, average highest temperature was $40.4{ }^{\circ} \mathrm{C}$ at noon 1400 hours and average lowest temperature was $21.25^{\circ} \mathrm{C}$ at 2400 hours. The subsurface temperature of soil at $10 \mathrm{~cm}$ depth also showed similar result and that temperature were observed lower in the early morning of hours, which gradually increased with the advancement of day, and it was peaked at $1300 \mathrm{hr}$ to $1600 \mathrm{hr}$. In four types of soil the amplitude of the daily temperature wave decreased in the order sand > peat $>$ red $>$ clay. Soil texture had a distinct influence on soil temperature and on soil heat flux. The finer textured materials had greater heat capacity and their normally greater thermal conductivity where as coarse textured (sand) had lower heat capacity, lower thermal conductivity that's why warmed up more rapidly. Among three condition, sandy soil emitted highest long wave radiation $\left(-649.88 \mathrm{Wm}^{-2}\right)$ in bare condition. The long wave radiation emitted by the surface was lower throughout the entire day when the soil was wet and has vegetation cover. The amplitude of emission of long wave radiation was same as compared with surface temperature. Coarse textured had poor heat capacity and might emitted high long wave radiation than fine textured. The diurnal changes in long wave radiation gradually increased soon at noon, reached a peak at about 1200 to 1500 hours and decreased with time.

\section{References}

Arya, S.P. 2001. Introduction to Micrometeorology. Second edition. Academic press, USA. pp. 46-61.

Bouyoucos, G.J. 1927. The hydrometer as a method for the mechanical analysis of soils. Soil Sci., 23:343353.

Brady, N.C. and Weil, R.R. 1999.The Nature and Properties of Soils. Chapter 1, 1.1-1.14; pp. 1-22.

Chang, J.H. 1968. Climate and Agriculture. An Ecological Survey. First edition. Alding publishing company. Chicago. pp. 87-97.

Cyril, N. and Ogagarue, D. 2012. An Investigation of Temperature Variation at Soil Depths in Parts of Southern Nigeria. American J., Environmental Engineering 2(5): 142-147.

Ellingson, R.G. 1995. Surface longwave fluxes from satellite observations: A critical review, Remote Sens. Environ., 51:89-97.

Gliessman, S.R. 1998.Agroecology: Ecological processes in sustainable agriculture. Ann Arbor Press, Chelsca, Michigan.

Hillel, D. 1982. Introduction to soil physics. Academic Press, San Diego, CA.

Hogue, E.J. and Neilson, G.H. 1986. Effect of root temperature and varying cation ratios on growth and leaf cation concentration of apple seedlings grown in nutrient solution. Can. J. Plant Sci. 66: 637-645.

Marshall, T.J. and Holmes, J.W. 1988. Soil Physics.2nd ed. Cambridge Univ. Press, New York.

Pan, H.L. and Mahrt, L. 1987. Interaction between soil hydrology and boundary-layer development. Bound.-Layer Meteor., 38:185-202.

Russell, E.W. 1973. Soil conditions and plant growth. Longman Group Limited, London, Great Britian,. 849 p.

Yakuwa, R. 1946. Uber die Bodentemperaturen in den verschiedenen Bodenarten in Hokkaido (On soil temperature in the diggerent soil types of Hokkaido). Geophys. Mag. (Tokyo) 14: 1-12. 